\title{
LAPAROSCOPIC CHOLECYSTECTOMY UNDER THORACIC EPIDURAL ANESTHESIA IN COMPARISON WITH GENERAL ANESTHESIA
}

\author{
Lobna T. El Durgham; Osama Y. Ahmad and Marwa M. Zakzouk \\ Anesthesia and Surgical Intensive Care Department, Faculty of Medicine, Zagazig University
}

\begin{abstract}
Background: Regional anesthesia for laparoscopic cholecystectomy (LC) is considered to have some advantages compared with general anesthesia. Patients can be awake and oriented at the end of the surgery and have less postoperative pain, nausea and vomiting. Problems related to general anesthesia such as oral and teeth injury during laryngoscopy, and a sore throat and stomach inflation as a result of mask ventilation might be avoided in a regional anesthetic setting.

Objective: the aim of the study is to compare between thoracic epidural anesthesia (TEA) and general anesthesia (GA) for LC regarding intraoperative hemodynamics, postoperative analgesia and cost.

Patients and methods: 116 patients undergoing elective laparoscopic cholecystectomy surgery in general surgery department in Zagazig University hospitals were randomly divided into two groups. Group A received GA with 1-2 $\mu \mathrm{g} / \mathrm{kg}$ fentanyl, $2 \mathrm{mg} / \mathrm{kg}$ propofol, $0.5 \mathrm{mg} / \mathrm{kg}$ cis-tracrium and isoflurane $2 \mathrm{MAC}$. Group B received $15 \mathrm{ml}$ bupivacaine $0.5 \%$ with 70-100 $\mu \mathrm{g}$ fentanyl in thoracic epidural catheter inserted at T 10-11 interspace. Both groups were given $30 \mathrm{ml}$ bupivacaine $0.375 \%$ intraperitoneal infradiaphragmatic after insertion of the trocar and insufflations of the peritoneal cavity before starting surgery.

Results: TEA proved to be having lower incidence of postoperative shoulder pain, postoperative nausea and vomiting (PONV) and lower cost than GA and a higher incidence of patient and surgeon satisfaction, hypotension and bradycardia.

Conclusion: TEA may be a good alternative to GA for LC.

Key words: thoracic epidural anesthesia, laparoscopic cholecystectomy, bupivacaine.
\end{abstract}

\section{INTRODUCTION}

L aparoscopic cholecystectomy under segmental thoracic epidural offers benefits over lumbar spinal anesthesia: the avoidance of urine retention and the benefit of day time surgery setting. In addition, the level of anesthesia achieved by spinal anesthetic is too low to perform laparoscopic surgery in some cases due to pooling of drug in the sacral region by lumbar lordosis. (1) Laparoscopic cholecystectomy was feasible under epidural anesthesia and it eliminated the need for postoperative analgesia. The authors believe that this approach should be considered for patients who require biliary surgery but who are not good candidates for general anesthesia due to cardiorespiratory problems. ${ }^{(2)}$

TEA for laparoscopic cholecystectomy is a safe alternative to general anesthesia in patients with severe respiratory disease. ${ }^{(3)}$

The physiological consequences of laparoscopy are related to the combined effects of intraperitoneal insufflations of $\mathrm{CO}_{2}$ to create pneumoperitoneum, alteration of patient position, and the effects of systemic absorption of $\mathrm{CO}_{2}$. ${ }^{(4)}$

\section{PATIENTS AND METHODS}

After approval of Local Ethical Committee, and taking a written informed consent 116 patients aged 20-60 years, of both sexes, ASA I-II undergoing elective laparoscopic cholecystectomy surgery in general surgery department in Zagazig University hospitals. Exclusion criteria include: patient refusal,
ASA III - IV, age <20 and $>60$, body weight more than $120 \mathrm{~kg}$, dysrhythmia by ECG, contraindication to epidural anesthesia (coagulation disorder, infection at puncture site, increased intracranial tension, and allergy to local anesthetics), history of alcohol or drug abuse, mental illness, spinal deformity, and acute cholecystitis.

Patients undergoing elective laparoscopic cholecystectomy surgery classified randomly into 2 groups.

On arrival to operating room, a suitable peripheral vein was cannulated in the left forearm. All patients were premedicated with midazolam 0.025-0.075 $\mathrm{mg} / \mathrm{kg}$ and pethidine $25-50 \mathrm{mg}$ intravenous. Antiemetic (metoclopramide 10-20 mg IV) was given to guard against nausea and vomiting, a preload of $500 \mathrm{ml}$ Ringer solution given before anesthesia.

Patient monitoring was started by pulse oximetry, ECG, NIBP, and $\mathrm{EtCO}_{2}$.

Group (A): 58 patients received preoxygenation followed by $1-2 \mu \mathrm{g} / \mathrm{kg}$ fentanyl, $2 \mathrm{mg} / \mathrm{kg}$ propofol, $0.5 \mathrm{mg} / \mathrm{kg}$ cis-tracrium, followed by endotracheal intubation. Maintenance of anesthesia with isoflurane $2 \mathrm{MAC}$ and mechanical ventilation using tidal volume $8-10 \mathrm{ml} / \mathrm{kg}$ to maintain $\mathrm{EtCO}_{2}$ between 40-45 mm Hg. Nasogastric tube was inserted after induction of anesthesia.

The peritoneal cavity was inflated by $\mathrm{CO}_{2}$ at an intraperitoneal pressure of 7-10 $\mathrm{mmHg}$. Both groups were given $30 \mathrm{ml}$ bupivacaine $0.375 \%$ (prepared by 
adding $22.5 \mathrm{ml}$ bupivacaine $0.5 \%$ to $7.5 \mathrm{ml} \mathrm{NS}$ $0.9 \%$ intraperitoneal infradiaphragmatic after insertion of the trocar and insufflations of the peritoneal cavity before starting surgery. After surgery, the neuromuscular blockade was reversed by neostigmine $0.05-0.07 \mathrm{mg} / \mathrm{kg}$ and atropine 0.01 $0.02 \mathrm{mg} / \mathrm{kg}$, followed by suction of the airway and extubation.

Postoperative analgesia was given using NSAIDs as ketorolac (10-30 mg) intravenous every 4-6 h or diclofenac sodium $(75-150 \mathrm{mg})$ intramuscular every 12-24 h.

Group (B): 58 patients received TEA T 10-11 interspace by a paramedian approach in sitting position under complete aseptic conditions. Local anesthesia infiltration was done by lidocaine $2 \%$ followed by epidural cannulation. The epidural space was identified using hanging drop method. The distance from skin to epidural space was calculated from the length of needle protruding from the skin. Epidural catheter $20 \mathrm{G}$ was placed and a test dose of $3 \mathrm{ml}$ lidocaine $2 \%$ with adrenaline (1: 200,000 by adding $1 \mathrm{mg}$ adrenaline to $200 \mathrm{ml}$ NS $0.9 \%$ ).

Injection of $15 \mathrm{ml}$ bupivacaine $0.5 \%$ is given in epidural catheter with 70-100 $\mu \mathrm{g}$ fentanyl, followed by $2 \mathrm{ml}$ bupivacaine $0.5 \%$ every one hour. If the patients feel shoulder pain with the onset of insufflations, incremental doses of ketamine $(0.25$ $0.5 \mathrm{mg} / \mathrm{kg}$ ) or propofol $(10-20 \mathrm{mg})$ were given till injection of intraperitoneal bupivacaine.

Postoperative analgesia was given using $4 \mathrm{ml}$ bupivacaine $0.25 \%$ every $4 \mathrm{~h}(2 \mathrm{ml}$ bupivacaine $0.5 \%$ plus $2 \mathrm{ml} \mathrm{NS} 0.9 \%$ ).

All patients in the 2 groups were continuously assessed and monitored by pulse oximetry, ECG, NIBP, $\mathrm{EtCO}_{2}$ and $\mathrm{PaCO}_{2}$ (pre-insufflation then after 10 minutes, $30 \mathrm{~min}, 60 \mathrm{~min}$, and $90 \mathrm{~min}$ after insuflation). Data was recorded every 15 minutes throughout the surgery.

Group (B) was monitored for: sensory block (onset: time from injection of bupivacaine till loss of sensation of the skin of anterior abdominal wall by pinprick, 15-20 min, level: desired block from T4 to T12).

If the sensory block is not adequate within 30 minutes, general anesthesia will be induced and the patient was excluded from the study.

Motor block: Motor block of anterior abdominal wall muscles and lower intercostal muscles, it is monitored by Bromage motor power score (1: Free movement of legs and feet, 2: Just able to flex knees with free movement of feet, 3: Unable to flex knees, but with free movement of feet, 4: Unable to move legs or feet.). ${ }^{(5)}$ Epidural catheter was removed after $24 \mathrm{~h}$, before patient discharge.

Both groups were compared according to:

HR (heart rate). Bradycardia (a decrease in HR more than $20 \%$ from the baseline) was treated by incremental doses of atropine, MAP (mean arterial pressure). Hypotension (a decrease in systolic blood pressure more than $20 \%$ from the baseline) was treated by incremental doses of ephedrine and intravenous crystalloids, $\mathrm{SaO}_{2}$ (arterial oxygen saturation), $\mathrm{EtCO}_{2}$ (end tidal $\mathrm{CO}_{2}$ ), $\mathrm{PaCO}_{2}$ (partial pressure of arterial $\mathrm{CO}_{2}$ ), postoperative VAS (visual analogue scale), anesthetic complications (intraoperative hypotension, bradycardia, postoperative shoulder pain and PONV) and cost. Patient satisfaction and surgeon satisfaction recorded by verbal rating scale (VRS) for satisfaction (1/5 very dissatisfied, 2/5 dissatisfied, $3 / 5$ neutral, $4 / 5$ satisfied, and 5/5 very satisfied).

\section{RESULTS}

All the data collected was fed into Statistical Package for Social Sciences (SPSS version 19). Data were compared by using the t-test and expressed as mean \pm standard deviation (Mean \pm $\mathrm{SD})$. Gender was compared by using the chi-square test. P-value of $<0.05$ was considered as significant. All cases were successfully completed laparoscopically, and there were no conversions to open cholecystectomy. Demographic data (age, body weight, height and sex) in the two groups shows no significant differences as regard the parameters. (Table 1)

In both groups, duration of surgery (min) was $60.5 \pm 12.3$, range $60-90 \mathrm{~min}$, and duration of anesthesia (min) 68.5 \pm 14.4 , range $90-100 \mathrm{~min}$. In current study, there were statistically significant differences between patient satisfaction and surgeon satisfaction in the two groups. (Table 2) Patient satisfaction was higher in group B (mean score 3.6) than group A (mean score 2.9), also surgeon satisfaction was higher in group B (mean score 3.8) than group A (mean score 3.5). As regard intraoperative HR (Table 3) and MAP (Table 4) there were statistically significant differences being lower in group B.

As regard intraoperative $\mathrm{SaO}_{2}$, there were statistically significant differences at $15 \mathrm{~min}, 30$ $\mathrm{min}, 45 \mathrm{~min}, 60 \mathrm{~min}, 75 \mathrm{~min}$ and $90 \mathrm{~min}$, being lower in group $\mathrm{B}$. (Table 5) As regard intraoperative $\mathrm{EtCO}_{2}$ (Table 6) and $\mathrm{PaCO}_{2}$ (Table 7) there were statistically significant differences being lower in the group A. 
As regard the postoperative VAS measurement there were a statistically significant differences at $1^{\text {st }}$ $\mathrm{h}, 2^{\text {nd }} \mathrm{h}, 4^{\text {th }} \mathrm{h}, 6^{\text {th }} \mathrm{h}, 8^{\text {th }} \mathrm{h}, 12^{\text {th }} \mathrm{h}, 16^{\text {th }} \mathrm{h}, 20^{\text {th }} \mathrm{h}$ and $24^{\text {th }} \mathrm{h}$, being lower in group B. (Table 8)

As regard the anesthetic complications: intraoperative hypotension and bradycardia there were a statistically significant differences, being lower in group A and more in the group B, while postoperative shoulder pain and PONV there were a statistically significant differences, being lower in group B and more in group A. (Table 9)

As regard intraoperative cost, there was a statistically significant difference between the two groups, being lower in group B. (Table 10).

Table 1: Patients characteristics in the two groups.

\begin{tabular}{|c|c|c|c|c|c|}
\hline & \multirow{2}{*}{$\begin{array}{c}\text { Age } \\
\text { (years) }\end{array}$} & \multirow{2}{*}{$\begin{array}{c}\text { Weight } \\
\text { (kg) }\end{array}$} & \multirow{2}{*}{$\begin{array}{l}\text { Height } \\
\text { (cm) }\end{array}$} & \multicolumn{2}{|c|}{ Sex } \\
\hline & & & & $\begin{array}{l}\text { M: n } \\
(\%)\end{array}$ & $\begin{array}{l}\text { F: } \mathbf{n} \\
(\%)\end{array}$ \\
\hline $\begin{array}{l}\text { Group A }(n=58) \\
\text { Mean } \pm \text { SD } \\
\text { Range }\end{array}$ & $\begin{array}{l}45 \pm 11.1 \\
20-60\end{array}$ & $\begin{array}{l}73.7 \pm 5.2 \\
60-80\end{array}$ & $\begin{array}{l}165 \pm 3.7 \\
155-172\end{array}$ & $23(39.6 \%)$ & $35(60.3 \%)$ \\
\hline $\begin{array}{l}\text { Group B }(n=58) \\
\text { Mean } \pm \text { SD } \\
\text { Range }\end{array}$ & $\begin{array}{c}44.4 \pm 15.3 \\
21-60\end{array}$ & $\begin{array}{l}73 \pm 5.5 \\
60-80\end{array}$ & $\begin{array}{l}166.5 \pm 3.1 \\
159-170\end{array}$ & $25(43.1 \%)$ & $33(56.8 \%)$ \\
\hline t test & 0.363 & 0.64 & 0.947 & $X^{2}=$ & 0.14 \\
\hline P value & 0.718 & 0.52 & 0.35 & & \\
\hline
\end{tabular}

SD: Standard Deviation, $\mathbf{M}$ : male, $\mathbf{F}$ : female, $\mathbf{X}^{\mathbf{2}}$ : chi-square test, $\mathbf{n}$ : number.

Table 2: Patient satisfaction and surgeon satisfaction in the two groups.

$\begin{array}{cc}\text { Patient } & \text { Surgeon } \\ \text { Satisfaction } & \text { Satisfaction }\end{array}$

\begin{tabular}{lcc}
\hline Group A $(\mathbf{n = 5 8})$ & $2.9 \pm 0.9$ & $3.5 \pm 0.4$ \\
Mean \pm SD & $2-4$ & $3-5$ \\
Range & & \\
\hline Group B (n=58) & $3.6 \pm 0.9$ & $3.8 \pm 0.2$ \\
Mean \pm SD & $3-5$ & $2-4$ \\
Range & 4.189 & 5.109 \\
\hline $\mathbf{t}$ test & $0.0001^{* *}$ & $0.0001^{* *}$ \\
\hline P value & & \\
\hline
\end{tabular}

Table 3: Intraoperative HR beat per min (bpm) changes in the two groups.

\begin{tabular}{|c|c|c|c|c|c|c|c|}
\hline & $\begin{array}{c}0 \text { min } \\
\text { (Base line) }\end{array}$ & $15 \mathrm{~min}$ & $30 \mathrm{~min}$ & $45 \mathrm{~min}$ & $60 \mathrm{~min}$ & $75 \mathrm{~min}$ & $90 \mathrm{~min}$ \\
\hline $\begin{array}{l}\text { Group A }(n=58) \\
\text { Mean } \pm \text { SD } \\
\text { Range }\end{array}$ & $\begin{array}{c}89.70 \pm 16.3 \\
63-131\end{array}$ & $\begin{array}{c}90.2 \pm 18.3 \\
55-137\end{array}$ & $\begin{array}{c}91.4 \pm 16.6 \\
62-122\end{array}$ & $\begin{array}{c}92.9 \pm 15.9 \\
62-129\end{array}$ & $\begin{array}{c}93.6 \pm 16.2 \\
58-145\end{array}$ & $\begin{array}{c}94.7 \pm 13.0 \\
77-117\end{array}$ & $\begin{array}{c}98.5 \pm 8.9 \\
90-110\end{array}$ \\
\hline $\begin{array}{l}\text { Group B }(n=58) \\
\text { Mean } \pm \text { SD } \\
\text { Range }\end{array}$ & $\begin{array}{c}85.5 \pm 12.2 \\
75-114\end{array}$ & $\begin{array}{c}82.93 \pm 14.6 \\
60-114\end{array}$ & $\begin{array}{c}85.5 \pm 10.6 \\
65-92\end{array}$ & $\begin{array}{c}85.6 \pm 13.3 \\
70-113\end{array}$ & $\begin{array}{c}91.9 \pm 14.8 \\
73-112\end{array}$ & $\begin{array}{c}91.6 \pm 13.6 \\
59-114\end{array}$ & $\begin{array}{c}96.4 \pm 17.0 \\
61-119\end{array}$ \\
\hline t test & 1.59 & 2.377 & 2.28 & 2.689 & 0.59 & 1.254 & 0.406 \\
\hline$P$ value & 0.115 & $0.019^{*}$ & $0.024 *$ & $0.008^{*}$ & 0.556 & 0.212 & 0.834 \\
\hline
\end{tabular}


Table 4: Intraoperative MAP changes in the two groups.

\begin{tabular}{|c|c|c|c|c|c|c|c|}
\hline & $\begin{array}{c}0 \text { min } \\
\text { (Base line) }\end{array}$ & $15 \mathrm{~min}$ & $30 \mathrm{~min}$ & $45 \mathrm{~min}$ & $60 \mathrm{~min}$ & $75 \mathrm{~min}$ & 90 min \\
\hline $\begin{array}{l}\text { Group A }(n=58) \\
\text { Mean } \pm \text { SD } \\
\text { Range }\end{array}$ & $\begin{array}{c}95.1 \pm 15.7 \\
64-126\end{array}$ & $\begin{array}{c}91.8 \pm 18.2 \\
56-122\end{array}$ & $\begin{array}{c}91.3 \pm 18.1 \\
46-130\end{array}$ & $\begin{array}{c}96.3 \pm 17.7 \\
52-145\end{array}$ & $\begin{array}{c}99.2 \pm 16.3 \\
64-144\end{array}$ & $\begin{array}{c}100.3 \pm 14.5 \\
75-140\end{array}$ & $\begin{array}{c}101.1 \pm 15.7 \\
76-129\end{array}$ \\
\hline $\begin{array}{l}\text { Group B }(n=58) \\
\text { Mean } \pm \text { SD } \\
\text { Range }\end{array}$ & $\begin{array}{c}94.3 \pm 14.5 \\
79-126\end{array}$ & $\begin{array}{c}90.3 \pm 13.5 \\
70-110\end{array}$ & $\begin{array}{c}82.7 \pm 14.1 \\
65-99\end{array}$ & $\begin{array}{c}85.8 \pm 14.5 \\
65-99\end{array}$ & $\begin{array}{c}88.1 \pm 15.9 \\
53-105\end{array}$ & $\begin{array}{c}90.4 \pm 18.3 \\
70-117\end{array}$ & $\begin{array}{c}95.1 \pm 10.3 \\
73-107\end{array}$ \\
\hline t test & 0.285 & 0.505 & 5.635 & 3.494 & 4.576 & 3.229 & 2.027 \\
\hline P value & 0.776 & 0.614 & $0.01 *$ & $0.001 * *$ & $0.01 *$ & $0.002^{*}$ & $0.04 *$ \\
\hline
\end{tabular}

Table 5: Intraoperative $\mathrm{O}_{2}$ saturation changes in the two groups.

\begin{tabular}{|c|c|c|c|c|c|c|c|}
\hline & $\begin{array}{c}0 \text { min } \\
\text { (Base line) }\end{array}$ & $15 \mathrm{~min}$ & $30 \mathrm{~min}$ & $45 \mathrm{~min}$ & $60 \mathrm{~min}$ & $75 \mathrm{~min}$ & $90 \mathrm{~min}$ \\
\hline $\begin{array}{l}\text { Group A }(n=58) \\
\text { Mean } \pm \text { SD } \\
\text { Range }\end{array}$ & $\begin{array}{l}98.8 \pm 1.3 \\
96-100\end{array}$ & $\begin{array}{l}98.9 \pm 0.9 \\
97-100\end{array}$ & $\begin{array}{l}98.9 \pm 0.8 \\
96-100\end{array}$ & $\begin{array}{l}99 \pm 0.9 \\
95-100\end{array}$ & $\begin{array}{l}99 \pm 0.9 \\
95-100\end{array}$ & $\begin{array}{l}99 \pm 0.8 \\
97-100\end{array}$ & $\begin{array}{l}99.3 \pm 0.6 \\
98-100\end{array}$ \\
\hline $\begin{array}{l}\text { Group B }(n=58) \\
\text { Mean } \pm \text { SD } \\
\text { Range }\end{array}$ & $\begin{array}{c}98.6 \pm 1.3 \\
95-100 \\
\end{array}$ & $\begin{array}{l}97.8 \pm 1.6 \\
96-100\end{array}$ & $\begin{array}{l}97.9 \pm 1.5 \\
96-100\end{array}$ & $\begin{array}{l}97.2 \pm 2.3 \\
95-100\end{array}$ & $\begin{array}{l}96.9 \pm 2.4 \\
94-100\end{array}$ & $\begin{array}{l}97.6 \pm 1.4 \\
96-99\end{array}$ & $\begin{array}{c}96.7 \pm 2.2 \\
97-99 \\
\end{array}$ \\
\hline t test & 0.828 & 4.726 & 4.532 & 5.822 & 6.24 & 6.612 & 8.683 \\
\hline P value & 0.409 & $0.000 * *$ & $0.000 * *$ & $0.000 * *$ & $0.000 * *$ & $0.000 * *$ & $0.000 * *$ \\
\hline
\end{tabular}

Table 6: Intraoperative $\mathrm{EtCO}_{2}$ changes in the two groups.

\begin{tabular}{|c|c|c|c|c|c|c|c|}
\hline & $\begin{array}{l}\text { 0 min } \\
\text { (Base } \\
\text { line) } \\
\end{array}$ & $15 \mathrm{~min}$ & $30 \mathrm{~min}$ & $45 \mathrm{~min}$ & $60 \mathrm{~min}$ & $75 \mathrm{~min}$ & $90 \mathrm{~min}$ \\
\hline $\begin{array}{l}\text { Group A }(n=58) \\
\text { Mean } \pm \text { SD } \\
\text { Range }\end{array}$ & $\begin{array}{l}40.9 \pm 1.2 \\
40-45\end{array}$ & $\begin{array}{c}42 \pm 1.5 \\
39-44\end{array}$ & $\begin{array}{c}43 \pm 1.8 \\
40-45\end{array}$ & $\begin{array}{c}43 \pm 2.2 \\
40-46\end{array}$ & $\begin{array}{l}43.6 \pm 1.3 \\
42-46\end{array}$ & $\begin{array}{c}43.1 \pm 0.8 \\
42-46\end{array}$ & $\begin{array}{l}42.6 \pm 0.6 \\
41-44\end{array}$ \\
\hline $\begin{array}{l}\text { Group B }(n=58) \\
\text { Mean } \pm \text { SD } \\
\text { Range }\end{array}$ & $\begin{array}{c}40.8 \pm 0.7 \\
40-42\end{array}$ & $\begin{array}{c}42.8 \pm 1.2 \\
40-46\end{array}$ & $\begin{array}{c}44.2 \pm 1.9 \\
40-50\end{array}$ & $\begin{array}{c}44.8 \pm 0.8 \\
44-46\end{array}$ & $\begin{array}{l}44.2 \pm 1.6 \\
40-46\end{array}$ & $\begin{array}{l}45.7 \pm 3.2 \\
40-49\end{array}$ & $\begin{array}{c}46.4 \pm 2.3 \\
44-50\end{array}$ \\
\hline t test & 0.548 & 3.311 & 3.945 & 5.856 & 2.217 & 8.312 & 12.175 \\
\hline$P$ value & 0.584 & $0.001 *$ & $0.000 * *$ & $0.000 * *$ & $0.029 *$ & $0.000 * *$ & $0.000 * *$ \\
\hline
\end{tabular}


Table 7: Intraoperative $\mathrm{PaCO}_{2}$ changes in the two groups.

\begin{tabular}{lccccc}
\hline & $\begin{array}{c}\mathbf{0} \text { min } \\
\text { (Base line) }\end{array}$ & $\mathbf{1 0}$ min & $\mathbf{3 0}$ min & $\mathbf{6 0} \mathbf{~ m i n}$ & $\mathbf{9 0} \mathbf{~ m i n}$ \\
\hline $\begin{array}{l}\text { Group A (n=58) } \\
\text { Mean } \pm \text { SD }\end{array}$ & $44.3 \pm 1.4$ & $44.4 \pm 1.4$ & $44.4 \pm 1.3$ & $45.6 \pm 1.5$ & $47.8 \pm 1.2$ \\
Range & $42-45$ & $43-46$ & $42-47$ & $44-48$ & $46-49$ \\
\hline Group B (n=58) & & & & & \\
Mean \pm SD & $44.4 \pm 1.3$ & $45.2 \pm 1.3$ & $45.8 \pm 1.8$ & $46.9 \pm 1.7$ & $48.4 \pm 2.2$ \\
Range & $42-44$ & $43-47$ & $44-48$ & $45-49$ & $46-52$ \\
\hline t test & 0.399 & 3.189 & 4.802 & 4.367 & 1.823 \\
\hline P value & 0.691 & $0.002^{*}$ & $0.000^{* *}$ & $0.000^{* *}$ & 0.07 \\
\hline
\end{tabular}

Table 8: Postoperative VAS measurement in the two groups.

\begin{tabular}{|c|c|c|c|c|c|c|c|c|c|}
\hline & $1^{\text {st }} h$ & $2^{\text {nd }} h$ & $4^{\text {th }} \mathrm{h}$ & $6^{\text {th }} h$ & $8^{\text {th } h}$ & $12^{\text {th }} h$ & $16^{\text {th }} h$ & $20^{\text {th }} h$ & $24^{\text {th }} h$ \\
\hline $\begin{array}{l}\text { Group A } \\
\text { Mean } \pm \text { SD } \\
\text { Range }\end{array}$ & $\begin{array}{c}4.4 \pm 0.3 \\
4-5\end{array}$ & $\begin{array}{c}3.7 \pm 0.2 \\
3-4\end{array}$ & $\begin{array}{c}3.6 \pm 0.2 \\
3-4\end{array}$ & $\begin{array}{c}2.3 \pm 0.3 \\
2-3\end{array}$ & $\begin{array}{c}2.4 \pm 0.3 \\
2-3\end{array}$ & $\begin{array}{c}2.5 \pm 0.3 \\
2-3\end{array}$ & $\begin{array}{c}1.5 \pm 0.4 \\
1-2\end{array}$ & $\begin{array}{c}1.4 \pm 0.3 \\
1-2\end{array}$ & $\begin{array}{c}0.8 \pm 0.2 \\
1-2\end{array}$ \\
\hline $\begin{array}{l}\text { Group B } \\
\text { Mean } \pm \text { SD } \\
\text { Range }\end{array}$ & $\begin{array}{c}3.6 \pm 0.4 \\
3-4\end{array}$ & $\begin{array}{c}2.5 \pm 0.4 \\
2-3\end{array}$ & $\begin{array}{c}2.4 \pm 0.3 \\
2-3\end{array}$ & $\begin{array}{c}1.2 \pm 0.2 \\
1-3\end{array}$ & $\begin{array}{c}1.2 \pm 0.1 \\
1-2\end{array}$ & $\begin{array}{c}1.3 \pm 0.2 \\
1-2\end{array}$ & $\begin{array}{c}1.1 \pm 0.1 \\
1-2\end{array}$ & $\begin{array}{c}0.8 \pm 0.2 \\
0-1\end{array}$ & $\begin{array}{c}0.6 \pm 0.3 \\
0-1\end{array}$ \\
\hline t test & 12.185 & 20.435 & 25.347 & 23.234 & 28.9 & 25.346 & 7.338 & 12.673 & 4.224 \\
\hline P value & $0.0001 * *$ & $0.0001 * *$ & $0.0001 * *$ & $0.0001 * *$ & $0.0001 * *$ & $0.0001 * *$ & $0.0001 * *$ & $0.0001 * *$ & $0.0001 * *$ \\
\hline
\end{tabular}

Table 9: Anesthetic complications in the two groups.

\begin{tabular}{lcccc}
\hline & $\begin{array}{l}\text { Intraoperative } \\
\text { hypotension }\end{array}$ & $\begin{array}{l}\text { Intraoperative } \\
\text { bradycardia }\end{array}$ & $\begin{array}{l}\text { Postoperative } \\
\text { shoulder pain }\end{array}$ & PONV \\
\hline Group A (n; \%) & $4(6.8 \%)$ & $10(17.2 \%)$ & $18(31 \%)$ & $12(20.6 \%)$ \\
\hline Group B (n; \%) & $8(13.7 \%)$ & $15(25.8 \%)$ & $9(15.5 \%)$ & $6(10.3 \%)$ \\
\hline t test & 1.49 & 1.27 & 3.19 & 2.37 \\
\hline P value & 0.223 & 0.259 & $0.048^{*}$ & 0.124 \\
\hline
\end{tabular}

Table 10: Cost in the two groups.

\section{Cost (EP)}

\begin{tabular}{lc}
\hline Group A (n=58) & \\
Mean \pm SD & $207.59 \pm 46.4$ \\
Range & $127.25-262.25$ \\
\hline Group B (58) & $128.2 \pm 32$ \\
Mean \pm SD & $126.25-133.25$ \\
Range & \\
\hline t test & 12.99 \\
\hline P value & $0.000 * *$
\end{tabular}




\section{DISCUSSION}

Regional anesthesia for LC is considered to have some advantages compared with general anesthesia. Patients can be awake and oriented at the end of the surgery and have less postoperative pain, nausea and vomiting. Problems related to general anesthesia such as oral and teeth injury during laryngoscopy, and a sore throat and stomach inflation as a result of mask ventilation might be avoided in a regional anesthetic setting. ${ }^{(6)}$

Epidural anesthesia was considered safe for laparoscopic cholecystectomy without associated respiratory depression as the respiratory control mechanism remains intact to allow the patients to adjust their minute ventilation. Moreover, the respiratory changes are less evident in awake patients under regional anesthesia and patients maintain an unchanged end tidal carbon dioxide. ${ }^{(7)}$

\section{A. As regard patients characteristics:}

In this study, the age ranged from 20-60 years in group $\mathrm{A}$ and 21-60 years in group $\mathrm{B}$, the weight ranged from $60-80 \mathrm{~kg}$ in the two groups, the height ranged from 155-172 $\mathrm{cm}$ in group A and 159-170 $\mathrm{cm}$ in group B. regarding sex, duration of surgery and duration of anesthesia, there were statistically insignificant differences between the two groups.

As regard patient satisfaction, the mean was higher in group B (3.6) than group A (2.9). As regard surgeon satisfaction, the mean was higher in group B (3.8) than group A (3.5).

In agreement with this study, Lee et al. ${ }^{(8)}$ who found that the patients were satisfied with the procedure and would recommend epidural technique to their friends and all surgeons agreed that there were no problems with relaxation of musculature, or the surgical technique, and answered that there was no difference between the epidural and general anesthesia.

Also, Zahoor et al. ${ }^{(9)}$ found that there was a notable increase in patient satisfaction with the EA as compared to GA for open cholecystectomy.

Gupta et al. ${ }^{(10)}$ found that all patients gave an overall satisfaction score 8 or above (a score scale ranging from 0 to 10 ).

\section{B. As regard intraoperative hemodynamics:}

In this study, there were statistically significant differences regarding HR and MAP in the two groups, being lower in group B. Intraoperative bradycardia occurred in 8 patients from 58 patients $(13.7 \%)$ and intraoperative hypotension occurred in 10 patients from 58 patients $(17.2 \%)$ in group B. This was related to the onset of pneumoperitoneum with decrease in venous return and vagal response to the stretching of the peritoneum in addition to the effect of epidural block.

The increase in HR and MAP in group A was related to the stress response of intubation.

In agreement with this study, Nishikawa et al. ${ }^{(11)}$ found that the incidence of intra- and postoperative hypotensive and bradycardiac episodes was significantly higher in the epidural group $(27 \%$ and $13 \%$ respectively) than in the IV group $(0 \%)$ while the incidence of hypertension was higher in the IV group (13\%) than in the epidural group $(0 \%)$.

Gupta et al. ${ }^{(10)}$ found transient hypotension in 8 from 48 patients who received TEA for LC which was treated effectively with one dose of $6 \mathrm{mg}$ IV mephentermine.

Lee et al. ${ }^{(8)}$ observed hypotension was in 8 patients from 12 patients who undergone LC under epidural anesthesia during surgery. These patients were treated successfully with intravenous ephedrine. Significant bradycardia, with a heart rate below 50 bpm, occurred in 2 patients who required an injection of atropine sulfate. A decrease of in the MAP is a well known adverse effect of spinal and epidural anesthesia covering the thoracic dermatome level, and is easily controlled with ephedrine administration.

Yi et al. ${ }^{(12)}$ documented a decrease in blood pressure from $135 / 79 \mathrm{mmHg}$ to $87 / 59 \mathrm{mmHg}$ and a decrease in heart rate from 89 beats/min to 67 beats/min without nausea, vomiting, or chest discomfort in a case report of a patient who had undergone pneumonectomy and undergone laparoscopic cholecystectomy under regional anesthesia.

Kim et al. (3) found severe hypotension and bradycardia due to an abrupt increase in intraabdominal pressure in a case of thoracic epidural anesthesia for laparoscopic cholecystectomy in an elderly patient with severely impaired pulmonary function tests.

Ross et al. ${ }^{(13)}$ found that 1 patient (10\%) from 10 patients in the general anesthesia cohort experienced bradycardia and hypotension at the start of insufflation.

C. As regard intraoperative $\mathrm{O}_{2}$ saturation:

As regard intraoperative $\mathrm{SaO}_{2}$, there were statistically differences regarding intraoperative $\mathrm{SaO}_{2}$, being lower in group $\mathrm{B}$. Intraoperative $\mathrm{SaO}_{2}$ was maintained above $94-99 \%$ in group B.

In agreement of this study, Mane et al. ${ }^{(14)}$ who studied a case series about combined spinal epidural anesthesia for laparoscopic appendectomy in adults 
and found that oxygen saturation was more than 95\% throughout the intraoperative period.

Agrawal et al. ${ }^{(15)}$ found that $\mathrm{SaO}_{2}$ remained within 95\%-99\% during thoracic epidural anesthesia for laparoscopic cholecystectomy.

Ross et al. ${ }^{(13)}$ found that $\mathrm{SaO}_{2}$ was significantly higher in the general anesthesia cohort compared with the epidural cohort at incision (99.7 versus 98.4, $\mathrm{p}=0.002)$ and closure (99.7 versus 98.6, $\mathrm{p}=$ 0.001) during LESS cholecystectomy under epidural versus general anesthesia.

\section{As regard intraoperative EtCO ${ }_{2}$ and $\mathrm{PaCO}_{2}:$}

In this study, there were statistically significant differences regarding intraoperative $\mathrm{EtCO}_{2}$ and $\mathrm{PaCO}_{2}$ being lower in the group $\mathrm{A}$.

Zundert et al. (16) found that under regional anesthesia the respiratory mechanism remains intact, and diaphragm the main inspiratory muscle is unaffected allowing the patient to adjust minute ventilation without any significant changes in ventilator parameters or $\mathrm{CO} 2$ levels.

Standring ${ }^{(17)}$ stated that another problem is the possibility of inadequate ventilation due to extensive thoracic nerve block. The main inspiratoty muscle, diaphragm, will be unaffected because it is innervated from cervical level, and expiration is normally a passive phenomenon. However, forceful expiration and coughing will be affected because they are generated primarily by the muscles of the anterior abdominal wall which are innervated by the thoracic nerve.

Mane et al. ${ }^{(14)}$ commented on another major concern was the consequence of paralyzing the primary expiratory muscles, those of the anterior abdominal wall. The study included ASA Grade I and II patients without respiratory disease, and thus this effect would have little consequence; therefore, there were no concerns about respiratory status at any time. In particular, no patient experienced dyspnea during abdominal insufflation perhaps because of the use of minimal tilt of the operating table and the use of low intra-abdominal gas pressure (maintained at $10 \mathrm{mmHg}$ ).

Agrawal et al. ${ }^{(15)}$ found that during thoracic epidural anesthesia for laparoscopic cholecystectomy, $\mathrm{PaCO}_{2}$ increased but remained within 39-51 $\mathrm{mmHg}$. The consistent increase in $\mathrm{PaCO}_{2}$ after pneumoperitoneum corroborates the hypothesis of absorption of $\mathrm{CO}_{2}$ from the peritoneal cavity.
Ross et al. ${ }^{(13)}$ found that $\mathrm{PaCO}_{2}$ levels were significantly higher with epidural anesthesia compared with general anesthesia at the time of incision (43.8 versus 29.7) and $5 \mathrm{~min}$ after insufflation (44.8 versus 31.8 ) but not after closure. Before irrigation of the diaphragm with local anesthetic, the average $\mathrm{EtCO}_{2}$ was $35.9 \pm 2.1$ in the general anesthesia cohort and $34.0 \pm 12.6$ in the epidural cohort. After irrigation, the average $\mathrm{EtCO}_{2}$ was $35.0 \pm 3.0$ for general anesthesia and $28.7 \pm$ 14.6 for epidural anesthesia. The change in $\mathrm{EtCO}_{2}$ after irrigation was not significant when compared between or within the cohorts.

Ross et al. ${ }^{(13)}$ reconfirmed that epidural anesthesia for laparoscopy does not cause ventilator depression. The $\mathrm{PaCO}_{2}$ has been reported to increase after $\mathrm{CO}_{2}$ pneumoperitoneum for spontaneously breathing patients.

Gupta et al. ${ }^{(10)}$ found that $\mathrm{EtCO}_{2}$ increased over the first 10 minutes from $30.65 \pm 4.12$ to $35.47 \pm 5.3 \mathrm{~mm}$ $\mathrm{Hg}$ and declined after deflation during TEA for LC.

E. As regard postoperative VAS:

As regard the postoperative VAS measurement there were statistically significant differences, VAS ranged from 0-5 in group A and 0-4 in group B.

Hodzic et al. ${ }^{(18)}$ found that postoperative pain intensity was lower in patients operated by laparoscopic technique compared to the open method, measured on the VAS, especially for the first and second measuring. This difference was pronounced throughout the entire postoperative period $(p<0,001)$. The pain intensity was significantly lower in patients treated with local anesthetic $(\mathrm{p}<0.05)$.

Ross et al. ${ }^{(13)}$ concluded that patients who received epidural anesthesia had significantly lower pain scores upon arrival to postanesthesia care unit (PACU) compared with patients who received general anesthesia $(4.2 \pm 3.0$ versus $8.4 \pm 1.1)$. Pain also was significantly less for the epidural anesthesia cohort at 20 and $35 \mathrm{~min}$ postoperatively. Resting and stressed pain scores were significantly lower in the epidural anesthesia cohort compared with the general anesthesia cohort when measured immediately before discharge from the hospital. Also resting postoperative VAS pain score at discharge was $4.7 \pm 2.5$ in general anesthesia versus $2.2 \pm 1.6$ in epidural anesthesia.

Demet et al. ${ }^{(19)}$ found that mean pain scores in the epidural group $(0.16 \pm 0.31)$ were lower than those in the intravenous group $(3.13 \pm 1.75)$, and concluded that epidural analgesia with a bupivacaine/fentanyl combination provided a statistically and clinically 
significant improvement in postoperative pain control compared with intravenous analgesia during the first $24 \mathrm{~h}$ following laparoscopic cholecystectomy.

Ahmed et al. ${ }^{(20)}$ found that administration of intermittent blouses of $0.125 \%$ bupivacaine is better than continuous infusion of $0.125 \%$ bupivacaine for post-operative pain relief after open cholecystectomy.

Against this study, Nishikawa et al. ${ }^{(11)}$ found that postoperative IV analgesia with buprenorphine were superior to epidural-based techniques, in terms of hemodynamic stability and patient satisfaction, in elderly patients undergoing laparoscopic cholecystectomy.

\section{F. As regard anesthetic complications:}

1. Intraoperative hypotension occurred in 4 patients (6.8\%) in group A and in 8 patients (13.7\%) in group B.

Lee et al. ${ }^{(8)}$ observed hypotension was in 8 patients from 12 patients $(66.6 \%)$ who undergone LC under epidural anesthesia.

Calvo et al. ${ }^{(21)}$ found that hypotension occurred in 10 patients $(50 \%)$ from 20 patients who received combined epidural and general anesthesia block (CEGAB) versus 9 patients $(47.5 \%)$ from 20 patients who received combined spinal and general anesthesia block (CSGAB).

2. Intraoperative bradycardia occurred in 10 patients $(17.2 \%)$ in group $\mathrm{A}$ and in 15 patients $(25.8 \%)$ in group B.

Lee et al. ${ }^{(8)}$ observed significant bradycardia in 2 patients $(16.6 \%)$ from 12 patients who undergone LC under epidural anesthesia.

3. Intraoperative shoulder pain occurred in 10 patients $(17.2 \%)$ in group B and not recorded in group A.

Lee et al. ${ }^{(8)}$ recorded that referred shoulder pain was a significant intraopertive event. Eleven patients experienced right shoulder pain or discomfort and 6 patients needed treatment. One of them received general anesthesia consequently. Incidence of shoulder pain in their study was higher than in the previous reports. The higher incidence of shoulder pain in their study might result from the surgical manipulation.

Ross et al. ${ }^{(13)}$ recorded intraoperative shoulder pain in 3 patients (30\%) from 10 patients in the epidural anesthesia cohort.

Gupta et al. ${ }^{(10)}$ observed the low incidence of intraoperative right shoulder pain in 15 patients (31.2\%) from 48 patients which could be attributed to low intraabdominal pressure of $10 \mathrm{~mm} \mathrm{Hg}$ combined with minimal table tilt and the instillation of $0.25 \%$ bupivacaine into right sub-diaphragmatic space and over the gall bladder.

Mane et al. ${ }^{(14)}$ found shoulder tip pain in 2 of 8 patients.

4. Postoperative shoulder pain occurred in 18 patients $(31 \%)$ in group A and in 9 patients $(15.5 \%)$ in group B.

Nishikawa et al. ${ }^{(11)}$ found that postoperative shoulder pain occurred in 0 patients from 15 patients $(0 \%)$ in IV group and in 1 patient from 15 patients $(7 \%)$ in epidural group.

Ross et al. ${ }^{(13)}$ reported postoperative shoulder pain in five patients: four who received epidural anesthesia (40\%) and one patient (10\%) who received general anesthesia.

Yasir et al. ${ }^{(22)}$ found that post operative shoulder tip pain had occurred only in 5 patients (10\%) from 50 patients who received low pressure pneumoperitoneum.

5. PONV occurred in 12 patients $(20.6 \%)$ in group A and in 6 patients $(10.3 \%)$ in group B. It was treated with metoclopramide $10-20 \mathrm{mg}$ IV.

Agrawal et al. ${ }^{(15)}$ found that PONV occurred in 3 patients $(5.1 \%)$ of 25 patients who received bupivacaine only and in 2 patients (3.4\%) of 25 patients who received bupivacaine plus clonidine during TEA for LC.

Zahoor et al. ${ }^{(9)}$ found that PONV after open cholecystectomy occurred in 11 patients from 51 patients $(21.5 \%)$ in the GA group and in only 1 patient (2\%) from 49 patients in TEA group.

Nishikawa et al. ${ }^{(11)}$ found that PONV occurred in 2 patients from 15 patients (13\%) in IV group and 3 patients from 15 patients $(20 \%)$ in epidural group.

Ross et al. ${ }^{(13)}$ reported postoperative nausea in one patient who received epidural anesthesia (10\%) and three patients $(30 \%)$ who received general anesthesia.

Gupta et al. ${ }^{(10)}$ reported postoperative nausea and vomiting in 3 patients from 48 patients who were treated with intravenous ondansetron. Low incidence in their study could be attributed to antiemetic prophylaxis with metoclopramide and ondansetron, avoidance of hypotension, adequate pain control and avoidance of postoperative parenteral opioids medication.

Demet et al. ${ }^{(19)}$ found that epidural group had a lower incidence of nausea/vomiting and sedation compared with intravenous analgesia.

G. As regard cost: 
The mean cost was $207.59 \pm 46.4$ in group A versus $128.2 \pm 32$ in group B.

Zahoor et al. ${ }^{(9)}$ concluded that EA proved more economical than GA in most of the cases.

\section{Conclusion:}

We concluded that TEA is effective, relatively safe and more economic than GA for anesthesia and postoperative analgesia in LC with the use of intraperitoneal bupivacaine and low pressure pneumoperitoneum. This is despite the relative difficulty of the technique and drawbacks of TEA as hypotension and intraoperative shoulder pain.

\section{RECOMMENDATIONS}

We recommend TEA with the use of intraperitoneal bupivacaine and low pressure pneumoperitoneum for anesthesia and postoperative analgesia in LC patients as an alternative to GA.

\section{REFERENCES}

1. Tzovaras G, Pratsas $\mathrm{K}$ and Georgopoulou S.: Laparoscopic cholecystectomy using spinal anesthesia. British Journal of Anesthesia; 99:744745, 2007.

2. Gramatica L Jr, Brasesco OE, Mercado Luna A, Martinessi V, Panebianco G, Labaque F, et al.: Laparoscopic cholecystectomy performed under regional anesthesia in patients with chronic obstructive pulmonary disease. Surgical Endoscopy and Other Interventional Techniques; 16: pp 472475, 2002.

3. Kim Yl, Lee JS, Jin HC, Chae WS, Kim SH.: Thoracic epidural anesthesia for laparoscopic cholecystectomy in an elderly patient with severely impaired pulmonary function tests. Acta Anaesthesiologica Scandinavica; 51(10):13946, 2007.

4. Irene E. Leonard, Anthony J. Cunningham: Anesthetic considerations for laparoscopic cholecystectomy, Best Practice \& Research Clinical Anesthesiology, vol. 16, No. 1, pp. 1-20, 2002.

5. Bromage PR: Epidural analgesia. Philadelphia: WB Saunders; 144, 1978.

6. Sinha R, Gurwara AK, Gupta SC.: Laparoscopic surgery using spinal anesthesia. JSLS; 12: 133-8, 2008.

7. Raju NP, Sivasashanmugam T, Ravishankar M.: Respiratory changes during spinal anesthesia for gynecologic laparoscopic surgery. J Anaesth Clinical Pharmacol; 26:681-3, 2010.

8. Ji Hyun Lee, Jin Huh, Duk Kyung Kim, Jea Ryoung Gil, Sung Won Min, and Sun Sook Hun.: Laparoscopic cholecystectomy under epidural anesthesia: a clinical feasibility study. Korean Journal of Anesthesia; 59 (6); 383-388, 2010.

9. Muhammad U. Zahoor, Rehan Masroor, Tassadaq Khurshid, Raheel Azhar and Malik M. Amjad
Yasin: Thoracic Epidural Anesthesia for Open Cholecystectomy, Journal of the College of Physicians and Surgeons Pakistan; Vol. 21 (11): 654-658, 2011.

10.Amit Gupta, Kumkum Gupta, Prashant K. Gupta, Nivesh Agarwal, Bhawna Rastogi: Efficacy of thoracic epidural anesthesia for laparoscopic cholecystectomy, Anesthesia: Essays and Researches; 5(2), Jul-Dec 2011.

11. Kohki Nishikawa, Saori Kimura, Yuki Shimodate, Motohiko Igarashi, and Akiyoshi Namiki: A comparison of intravenous-based and epiduralbased techniques for anesthesia and postoperative analgesia in elderly patients undergoing laparoscopic cholecystectomy, Journal of Anesthesia;21:1-6, 2007.

12.Jae-Woo Yi, Soo-Eun Choi, and Jun-Young Chung: Laparoscopic cholecystectomy performed under regional anesthesia in patient who had undergone pneumonectomy, A case report, Korean J Anesthesiol; 56(3): 330-3, 2009.

13. Sharona B. Ross, Devanand Mangar, Rachel Karlnoski, Enrico Camporesi, Katheryne Downes, Kenneth Luberice, et al.: Laparo-endoscopic singlesite (LESS) cholecystectomy with epidural vs. general anesthesia Surgical Endoscopy; Volume 27, Issue 5, pp 1810-1819, 2013.

14.Rajesh S. Mane, Manjunath C. Patil, K. S. Kedareshvara, C. S. Sanikop: Combined spinal epidural anesthesia for laparoscopic appendectomy in adults: A case series, Saudi Journal of Anesthesia, Vol. 6, Issue 1, January-March 2012.

15.Malti Agrawal, A. P. Verma, L. S. Kang: Thoracic epidural anesthesia for laparoscopic cholecystectomy using either bupivacaine or a mixture of bupivacaine and clonidine: A comparative clinical study Anesthesia: Essays and Researches; 7(1); Jan-Apr 2013.

16. Van Zundert AA, Stultiens G, Jakimowicz JJ, van den Borne BE, van der Ham WG, Wildsmith JA.: Segmental spinal anesthesia for cholecystectomy in a patient with severe lung disease. $\mathrm{Br} \mathrm{J}$ Anesth 2006; 96:464-6.

17.Standring S.: Gray's anatomy. 39th edition. Edinburgh: Elsevier; 1084-6, 2005.

18.Hodžić Enes, Imamović Semir, Hasukić Šefik, Majdančić Husnija, Imamović Goran: Postoperative pain in open vs. laparoscopic cholecystectomy with and without local application of anesthetic, Medicinski Glasnik, Volumen 8, Number 2, 243248, August 2011.

19.Demet Erol, Sezgin Yilmaz, Coskun Polat, Yuksel Arikan: Efficacy of Thoracic Epidural Analgesia for Laparoscopic Cholecystectomy, Adv Ther.; 25(1):45-52, 2008.

20.Ahmed S, Khan RA, Khurshid T, Boota M, Ishaque M. and Waseem SHM.: Postoperative analgesia 
following open cholecystectomy; is intermittent epidural bupivacaine bolus administration more effective than continuous administration?, Professional Med J;18 (3): 411-417, 2011.

21.Patricia Calvo-Soto, Benjamín Trujillo-Hernández, Alicia Martínez-Contreras, Clemente Vásquez: Comparison of combined spinal and general anesthesia block and combined epidural and general anesthesia block in laparoscopic cholecystectomy, Rev Invest Clin; 61 (6): 482-488, 2009.

22. Mir Yasir, Kuldeep S. Mehta, Viqar H. Banday, Aiffa Aiman, Imran Masood, Banyameen Iqbal: Evaluation of post operative shoulder tip pain in low pressure versus standard pressure pneumoperitoneum during laparoscopic cholecystectomy, the surgeon; 71-74, 2012. 